\title{
Who are we online? The interplay between online identity formation and Christian marriages
}

\begin{tabular}{|c|c|}
\hline \multicolumn{2}{|c|}{$\begin{array}{l}\text { Authors: } \\
\text { Chantal Ferreira }^{1} \\
\text { Hannelie Yates }^{1} \\
\text { Alfred R. Brunsdon }\end{array}$} \\
\hline \multicolumn{2}{|c|}{$\begin{array}{l}\text { Affiliations: } \\
{ }^{1} \text { Unit for Reformational } \\
\text { Theology and the } \\
\text { Development of the } \\
\text { South African Society, Faculty } \\
\text { of Theology, North-West } \\
\text { University, Potchefstroom, } \\
\text { South Africa }\end{array}$} \\
\hline \multicolumn{2}{|c|}{$\begin{array}{l}{ }^{2} \text { Unit for Reformational } \\
\text { Theology and the } \\
\text { Development of the } \\
\text { South African Society, } \\
\text { Faculty of Theology, } \\
\text { North-West University, } \\
\text { Mahikeng, South Africa }\end{array}$} \\
\hline \multicolumn{2}{|c|}{$\begin{array}{l}\text { Corresponding author: } \\
\text { Chantal Ferreira, } \\
\text { chantal.ferreira@yahoo.co.za }\end{array}$} \\
\hline \multicolumn{2}{|c|}{$\begin{array}{l}\text { Dates: } \\
\text { Received: } 18 \text { Mar. } 2021 \\
\text { Accepted: } 23 \text { July } 2021 \\
\text { Published: } 23 \text { Sept. } 2021\end{array}$} \\
\hline \multicolumn{2}{|c|}{$\begin{array}{l}\text { How to cite this article: } \\
\text { Ferreira, C., Yates, H. \& } \\
\text { Brunsdon, A.R., 2021, } \\
\text { 'Who are we online? The } \\
\text { interplay between online } \\
\text { identity formation and } \\
\text { Christian marriages', } \\
\text { HTS Teologiese Studies/ } \\
\text { Theological Studies } \\
\text { 77(4), a6630. https://doi. } \\
\text { org/10.4102/hts.v77i4.6630 }\end{array}$} \\
\hline \multicolumn{2}{|c|}{$\begin{array}{l}\text { Copyright: } \\
\text { (C) 2021. The Authors } \\
\text { Licensee: AOSIS. This } \\
\text { is licensed under the } \\
\text { Creative Commons } \\
\text { Attribution License. }\end{array}$} \\
\hline \multicolumn{2}{|l|}{ Read online: } \\
\hline arping & $\begin{array}{l}\text { Scan this QR } \\
\text { code with your } \\
\text { smart phone or } \\
\text { mobile device } \\
\text { to read online. }\end{array}$ \\
\hline
\end{tabular}

Digital technologies have become an integrated part of everyday life, and this development has not left relationships untouched. A need exists for theological reflection on the interaction between the dynamic contexts of the digital age and Christian marital relationships. The relational implications of the digital age are quite vast; therefore the focus of the article will be limited to online identity formation as a particular challenge of the digital age. Employing the method of a literature study within the scientific field of practical theology, this article explores the interplay between online identity formation and Christian marriage. It suggests that online identity formation exists around a reciprocal interaction with two prominent qualities of Christian marriages: The expansion of the self and one-ness. When considering the interplay between online identity formation and Christian marriage, awareness can be created regarding the marital implications of spouses' online engagements, which may enhance contextual pastoral care with a relational focus within the digital age.

Contribution: The article contributes to practical theological reflection on challenges posed to Christian marriages by the digital age. It is aimed at stimulating pastoral thinking regarding online identity formation and its adverse effects on so-called one-ness in Christian marriages that can enhance pastoral care with a view on the flourishing of couples in the digital age.

Keywords: Christian marriages; digital age; identity play; online identity; online identity formation; pastoral care.

\section{Introduction}

This article aims to provide a practical theological perspective on the interplay between online identity formation and Christian marriages. ${ }^{1}$ Reflecting on relationships in the digital age brings about a realisation of the complex nature of this context. Various questions have been raised and extensively answered in the literature relating to the interaction between the digital age and relationships. Notable authors in this field include Baym $(2010,2015)$, Turkle $(2011,2016)$ and Boyd (2014). Considerable focus is found on the effects of online engagements on romantic relationships, especially pertaining to social networking sites (SNSs) of which Facebook received a great amount of attention because of its popularity (Burton 2017:1; Carter 2015:2; Clayton, Nagurney \& Smith 2013:717; Marshall 2012:521). Research has been performed on marital relationships in the context of the digital age (Abramians 2016:vii). However, it seems as if the construct of 'marriages' is dealt with in a generic manner. Research related to this topic in most cases does not reflect a focus on religion or a particular faith tradition as a possible factor in the relation between the context of the digital era and the relational space of marriage (Burton 2017:3-4).

Upon conducting a quantitative study with 71 married participants from a local church of 1200 members in the USA, Burton $(2017: 40,51)$ established that there was no positive correlation between the number of hours spent on social media and the behaviour of married individuals. The online presence of spouses as such, therefore, does not cause marital discord. This indicates a need for further research towards identifying the elements of SNS (and of the digital age in general - author's insertion) that place strain on Christian marriages (Burton 2017:52-53). Once this has been determined, possible praxis guidelines can be formulated for supporting Christian marriages pastorally in the digital age. This article argues that the possibility of forming multiple online identities might be one of the specific challenges of the digital age that causes Christian marriages to experience tension.

1.This article forms part of a larger project, namely a PhD study conducted by the first author entitled, "Enhancing the resilience of Christian marriages in the digital age: A pastoral study'. Achieving the aim of the present article will be imperative towards constructing a meaningful pastoral response with a view to the enhancement of the resilience of Christian marriages in a digital age. This is the first of three articles that will comprise the overall project. Article two focussed on concept clarification and article three integrated the findings of the first two articles in order to present a pastoral perspective on the resilience of Christian marriages in a digital age. 
The research question that this study aims to address is: 'what is the interplay between online identity formation and Christian marriages?' Cloete (2019:vii) conceptualises the term 'interplay' as an emphasis on a constant interaction between two concepts and how this interaction causes reciprocal influence. Therefore, the aim of this article is to investigate and articulate the constant interaction between online identity formation and Christian marriages with the purpose of discovering how these two phenomena influence each other.

Employing the method of a literature study within the field of practical theology, this article will start off by clarifying the context of the digital age, including a broad overview of potential opportunities and challenges relating to marriage relationships. Subsequent to a brief explanation concerning the transitions in perspectives around identity formation, the concept of online identity formation is explored. On the basis of this orientation, the article explores the interplay between online identity formation and Christian marriages with a view to discussing it from a practical theological perspective. The literature studies conducted in the execution of the research made use of databases such as EBSCO host and focused on literature that investigated the influence of digital age on marriages, mainly since 2010.

In this article, the focus will be on Christian marriages in particular, as marriage within the Christian paradigm resembles an ethical framework highly susceptible to challenges imposed by the digital age. In our understanding, the concept of Christian marriages includes spouses that belong to the Christian faith, have unique theological resources at their disposal to build resilience and can be pastorally supported and cared for as informed by a Christian theological perspective. No qualitative differentiation between specific expressions of Christian marriages, for example, Roman Catholic, Protestant and such is made, as Christian marriage is universally understood to represent the same basic qualities as described in Scriptures.

\section{The digital age: A contextual orientation}

The digital age is defined as the current environment in which digital media and technologies are complexly present within all spheres of life. This brings about rapid transformations in the diverse mediums that people use to connect with one another, creating a dynamic interactive social space (Baym 2015:1; Cloete 2015:1; Hertlein \& Webster 2008:445; Joubert 2010:48). Although researchers assign different titles to this environment, the one common characteristic is the prominent role of digital technologies in the lives of people (Van den Berg 2018:91). The digital age is recognised by its hypertextuality, that is, the interactive nature of digital technologies, and its automation, that is, the ability of digital technologies to be manipulated and altered by people (Cloete 2015:2) ${ }^{2}$. In the digital age, it can be said 2.See Miller (2020:20-24) for an elaborated definition of both hypertextuality and automation in a digital age. that people are creators and creations of technology (Cloete 2015:2; Joubert 2010:50) because of the increasing influence of digital technologies on meaning-making and the value of relationships (Cloete 2017:1-2; Louw 2016:411-413; Van den Berg 2018:4-9).

The various ways in which users choose to interact with digital technologies and the various factors that accompany these technologies evoke either positive or negative relational implications. The former includes increased frequency of connections between people, which can contribute to relationship quality (Carpenter \& Spottswood 2013:1531; Turkle 2016:11-12) as well as the ability of spouses to connect with each other and maintain their relationship even though they are separated by distance for extensive periods (Larsen, Clauss-Ehlers \& Cosden 2015:219; O'Keefe 2018:129-130). There are also various avenues to form new relationships online, whilst such formation may have been challenged offline because of differences in age, gender or culture (Baym 2015:114-118).

Research also shows that the context of the digital age, however, also poses unique challenges for relationships (Nielsen 2019:113). Increased opportunities for mediated connection may bring into question the authenticity of the relationship (Baym 2015:5) and cause disengagement during face-to-face interaction (Abramians 2016:10). This can increase the feeling of loneliness and jeopardise a person's capacity for empathy (Turkle 2011:11-12, 2016:4). The existence of SNSs and the possibility of engaging in virtual relationships by means of alternative online identities increase the opportunity for partners to seek intimate relationships at the risk of their primary relationship (Burton 2017:17-18; Carter 2015:33; McInturff 2018:56).

This mixture of constructive and destructive qualities provides a complex environment for relationships. This article focuses on one challenge of this complex relational environment of our digital age, namely identity formation. Various authors agree that, within this environment, a unique connection between relationships and identity formation emerges (Baym 2015:188; Cloete 2015:2). Baym (2015:5) states that digital media calls 'into question the very authenticity of our identities, relationships and practices'. The process of identity formation within the digital age has, therefore, acquired unique and intriguing labels such as 'identity bending' (Bailenson 2013:xiv), 'identity play' (Miller 2011:173) and 'the algorithmic self' (Turkle 2016:81-85). Bailenson (2013) mentions identity bending whilst discussing the creation of avatars. He elaborates on the infinite plasticity of online identities, and how this affects an individual's offline identity. In contrast to Bailenson (2013), Miller (2011) does not believe that online identity plays a major role in users' offline identities. Instead, for him, the alternations between multiple online identities exist on a pragmatic level to enable the user to accomplish certain tasks in a virtual world (Miller 2011:173-175). In her turn, work performed by Turkle (2016:81-85), around the algorithmic self, concerns the influence of various algorithms when it comes to online 
identity formation. She explains how identity formation on Facebook and online gaming platforms are altered on the basis of the reaction one receives from one's audience. This causes that certain truthful elements of one's identity are left out or transformed that, in turn, causes self-reflection as well as confusion regarding who the self really is.

Before elaborating more on identity formation in the digital age, it is important to understand the changes that occurred in perspectives surrounding the construct of identity formation. The dynamic context of the digital age, as described above, which brought forth the newly identifying labels mentioned, surely challenges one or two traditional understandings relating to the process of identity formation. To gain understanding regarding this challenge, the article subsequently examines the life cycle theory as proposed by Erik Erikson ${ }^{3}$.

\section{Theoretical developments in the understanding of identity formation}

Erikson's theory of life cycle development historically served as an important foundation for pastoral ministry. Erikson connected the process of identity formation to the life stage of adolescence (Bingaman 2006:84-85). Research shows that people will live longer and therefore go through multiple transitions in life (Gratton \& Scott 2016:1-21), which will present new opportunities for identity adjustment, depending on different roles in different phases of life. Wright (2019:34-37) places identity development predominantly within the phase of adolescence and continues to explain how theories of Paul Ricoeur, Charles Taylor and Robert Kegan show that identity formation is a developmental task that takes place continually throughout a person's lifetime, not least because it contributes to the process of making meaning.

One of the biggest challenges of using Erikson's theory is that it has been rigidly applied to a particular stage of life, disallowing the necessary flexibility to accommodate the complexities of life as we know it today (Bingaman 2006:87; Erikson 1998:345-347). In Erickson's defence, the prominent existence of the digital age did not signify the context in which his research took place. It is, therefore, probable that the pressing need for flexibility regarding the life cycle and the various stages of life did not exist to the same extent. If more flexibility could be brought into Erikson's theory today, it could still serve as a valuable guiding framework for pastoral care and counselling. Bingaman (2006:87-88) advocates for this flexibility by using the example of identity formation that should not be limited to the phase of adolescence but should rather be understood as a lifelong developmental task.

3.The researcher acknowledges that there exist other developmental theories that can also be applicable to the current study. Examples of such can be the life span development Putney \& Johthesch in thes different theor Sugarman 2001) shows the prominence of his work in regard to developmenta theories, especially pertaining to development throughout childhood and adult life. This together with the relevance of Erikson's work for pastoral studies was the motivation for elaborating on his theory of life cycle development.
Although adolescence is still viewed as an important life phase where identity formation as development task is prominent, the digital age complicated this process by offering multiple opportunities for identity formation in other phases of life as well. It can be said that, in the digital age, identity should not be accepted as something static that is set in stone by the time of adulthood. Instead, identity within the digital age is understood to be fluid ${ }^{4}$, taking on different shapes in different phases of life and accommodating multiple self-presentations on various digital platforms. This brings into focus the unique opportunities that exist in the digital age relating to identity formation.

\section{Online identities and identity play}

On entering virtual reality, physical and temporal limits are suspended, and one discovers numerous landscapes of meaning, each of which presents the opportunity to create new selves and new worlds (Van den Berg 2012:430). The multiple opportunities to create and re-create one's online identities open numerous options of self-description and self-presentation, and these raise questions concerning authenticity and congruent selves within relational spaces. At the inception of the age of virtual engagement, the majority of interactions on gaming platforms and chat rooms took place by means of anonymous identities. Recently, SNSs have, however, brought greater alignment between a person's online and offline identity (Dereli 2019:25). The extent to which individuals' online and offline identities align is, therefore, no longer clear. This makes it even more challenging to measure authenticity and congruency in the digital age. Individuals now have the option to engage in online gaming and simultaneously maintain online profiles on various SNSs, which causes some presentations of the self to be anonymous and some to be identifiable. This raises the question: who are we online? Is the online self the real self, or does it comprise ideal or romanticised selves? And how does this influence a person's offline identity and interpersonal relationships?

Research shows that determining where a person's real self ends and begins as related to online and offline existence would be impossible to accomplish, as these 'two spaces are intertwined irreversibly' (Dereli 2019:27). Determining who we are online can be achieved with greater efficiency by understanding the phenomenon of 'identity play'. This entails the option to play around between various selfcreated online profiles. In this sense, virtual reality can be compared to a stage where the various characters at play are

4.Sherry Turkle's understanding of the 'fluidity of the self' evolved over time. In Life on the Screen published in 1995, Turkle (1995:263) mentions the possibility that the internet can encourage thinking 'of ourselves as fluid'. Alone Together released in 2011 contains various references to the fluidity of the self (Turkle 2011:160, 179, 260 \& 261). Here, Turkle $(2011: 260)$ begins to question the certainty of fluid identities online: all activities on the net can be traced, so how fluid is that identity really? One will never be able to totally erase one's self-created online identities because of its electronic trace, which implies a constant tension that exists between permanence and fluidity of identities in a digital age. In Turkle's latest book peclaiming Conversation (2016), the self is not only explained as fluid, but as Reclaiming Conversation (2016), the self is not only explained as fluid, but as algorithmic, as it is no longer only the user that creates the online identity, but algorithms contribute to this (see Turkle 2016.81-85). For the purpose of this article, 'fluididentities' is preferred, as it serves as the most appropriate concept fo the discussion concerning the interplay between online identities and Christian marriages. For more information on the development of the concept of fluid identities, see Miller (2011:162-165). 
self-presentations of its creators. One's online character's features and behaviours can be altered at any given time according to one's liking and according to the feedback received from the audience. In the case of online gaming, with the options of creating avatars, ${ }^{5}$ this phenomenon of identity play has been taken to what gamers often call 'the next level'. A more intense stage of engagement with identity play is made possible in a virtual world.

The concept of identity play is, however, not only found in the online gaming environment. The fact that SNSs allow users to create multiple accounts on the same platform (Cravens Leckie \& Whiting 2013:328) creates the possibility to experiment with one's online identity within these environments and provides the option to create false accounts. In the extant literature, the observation has been made that the majority of users' online and offline identities align to a great extent, and instead of presenting false information online, users would rather omit certain qualities of the self to present a perfect version of the self (Ferreira 2016:37). The negotiation between multiple portraits of the self, therefore, exists as a complicated process within the digital age. Empirical research further shows that users' online gaming behaviour and identity eventually do influence his or her offline behaviour and identity (Yee, Bailenson \& Ducheneaut 2009:305-306). A similar crossinfluence exists between SNS presentations online and offline, which can lead to a change in one's self-perception (Halpern, Katz \& Carril 2016:117, 121). Healthy interaction on the sporting field of identity play requires stable guidelines and awareness that the creation and management of multiple online identities do, in fact, affect the creator's offline identity.

According to Turkle (2011), identity play, which involves multiple versions of the self, is not necessarily a negative phenomenon:

When identity is multiple in this way, people feel whole not because they are one but because the relationships among aspects of the self are fluid and defensive. We feel 'ourselves' if we can move easily among our many aspects of self. (p. 194)

On examining extant research around fluid identities and identity play within the digital age, one senses nonetheless that these phenomena may give rise to confusion regarding the identity of the authentic self. Baym (2015:3-5) explains that a 'boundary flux' that exists within the digital age brings about deep confusion concerning what is real and what is not. The aim of expounding 'who we are online' would, therefore, not be to question whether the online persona is a true reflection of the offline self. Instead, it would question the level of self-awareness, clarity and ownership in regard to one's authentic and congruent identity in the midst of managing multiple portraits of the online self. Plural identities can create disorientation (Schweitzer 2004:60-61) that confronts relationships with questions and challenges. The subsequent section, therefore, examines the relational implications of online identity formation as it pertains to Christian marriages.

\section{The interplay between online identity formation and Christian marriages}

A prominent connection exists between identity formation and relationships. The self-expansion model as posed by Aron and Aron (1996:49) explains that individuals have a desire to expand the self, whilst a significant way by which this is accomplished is to include 'others in the self through close relationships'. Dreyer and Van Aarde (2007:636) explain that expansion and growth of the self take place with a view to the personal and collective identity of the two spouses in a marriage relationship. Because of the marriage relationship, the spouses may no longer view their identity as individualistic but in relation to each other. ${ }^{6}$ This expansion reminds of the concept of fluid identities and the fact that, in the digital age, identity formation is a lifelong process where the marital relationship contributes considerably to the continual formation of the self. For instance, a spouse's need for intimacy may confront one with a growth area in one's identity, just as online identity formation on SNS and gaming platforms can cause self-reflection and growth in one's identity. Although online identity formation does pose certain challenges for relationships, it, therefore, also contains opportunities for growth, confirming the reciprocal interplay between online identity formation and relationships. With this in mind, the present article underlines the unique ways in which the self can expand within the specific environment of Christian marriage and the interplay that exists between that environment and online identity formation.

Louw (2012:90-92) explains the process of marriage as comprising four consecutive stages:

1. The embryonic stage, where authenticity is vital and the possibility of the formation of a relationship is explored.

2. The stage of contact, signifying relationship building where mutuality as togetherness, is discovered.

3. The stage of contract, where true commitment develops implying a covenantal relationship. In this stage, the following question comes into existence: 'What can I share with you in order to safeguard your identity and dignity'?

4. The stage of growth. For continual growth to take place in the long-term, the 'we-space' has to be as important as the 'me-space'. Trust, faithfulness, reconciliation, forgiveness and grace have to exist within the relationship to create its ongoing renewal.

Marriage should not be seen as a linear development with an end goal in mind: instead, it should be viewed as a circular process (Louw 2012:90). The above overview shows

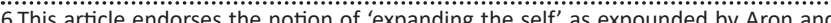
Aron (1996:50), which entails that marriage partners do not necessarily lose their Aron (1996:50), which entails that marriage partners do not necessarily lose the individual identity completely. Instead, it refers to a process of gradually enlarging the self, broadening one's identity or awareness by including another person in the process of its formation. 
that this circular process originates from a strong individualistic focus that later develops into a relational focus as the relationship grows into deeper levels of commitment and intimacy. In accordance with Christ's love for his church, the relational element of marriage in fact receives more focus than the individual element (Dreyer \& Van Aarde 2007:645). In this context, the theological perspective on the concept of plural identities held by Schweitzer (2004) states that plurality and relationality are interconnected:

[T] he relational character of self and identity obviously contradicts all individualistic views of human existence. A relational self is never unitary in the sense of being centred exclusively in the human person itself. This is why the notion of a plural self can be helpful for realising the importance of the relational character of the self, which is central to the Christian understanding. (p. 61)

But what does the digital age bring to these notions? It is evident that the concept of managing multiple identities within the digital age can contribute to one's understanding of identity as a relational construct. To a certain extent, this aligns with the notion of Turkle (2011:194) that identity play in the digital age can enhance a person's self-understanding. It is, however, important to notice that Turkle does not separate this statement from its strong relational component. An important key to the current study is that identity play and fluid identities within the digital age should not be accepted as processes in isolation: the strong relational element should not be overlooked. Carpenter and Spottswood (2013:1533) explain that the expansion of the self that takes place as a romantic relationship grows in intimacy should also be visible in one's behaviour, especially in an online environment. The striking question that does come to mind concerns the individualistic focus and individualistic behaviour that relate to online identity formation that strongly contradicts the understanding of being focused on the we-ness within marriage.

Halpern et al. (2016) performed an empirical study aimed at determining the effects of 'selfies' on romantic relationships. They discovered that selfies encourage a strive towards the perfect online self that entails a constant process of alteration, eventually influencing one's self-perception offline and one's offline relationships. Individuals 'shift their self believes to correspond to' what the public perceives, resulting in too much focus on the self and less focus on the other, thus jeopardising the intimacy of the primary relationship (Halpern et al. 2016:115-117). The challenge with this 'selfie' culture is that all the focus resorts to the picture taker and the fact that the person in the picture should be presented as flawless, resonant with the issue of identity play within an online world that revolves around creating the perfect picture of the self, which signifies a self-centred system and enhances the possibility of compromising the value of humility and relationality within marriage. It becomes patent that the first dimension of the interplay between online identity formation and Christian marriages exists in the tension between self-focus and focus on the other in relation to the we-space of the relationship. Though in the various phases of life, identity development may include the self-consumed culture that trademarks the digital age, when it comes to marriage, the situation is much different: as spouses desire to grow in intimacy, healthy navigation between the tension points of self-love and love for the other must develop. The second dimension of this interplay contains the constant presentation and formation of the perfect self, which contradicts the value of vulnerability and authenticity within relationships, especially in Christian marriages.

According to Bingaman (2006:88), the challenge of life is to bring authentically the totality of ourselves into a relationship with God and others in order to experience genuine intimacy. An essential factor of intimacy in marriage revolves around vulnerability and authenticity. It is within the relationship with one's spouse where one may have the expectation to share all of life, including one's weaknesses and hurts. However, this authentic sharing of one's vulnerability is not always the true lived experience in many marriages and is also not true in the case of many Christian marriages.

Schweitzer further expounds on this principle of being authentically broken. 'Relationality requires a fragmented [imperfect] self because the perfect self does not need relationships' (Schweitzer 2004:62). Relationship with God makes wholeness and healing possible, and relationships with others make the expansion of the self possible. In contrast to this, the characteristic of the 'perfect self' in online identities can suggest that one has to be flawless even though one is constantly confronted with one's own imperfections. Furthermore, it creates the idea that an individual could be without failings or maybe have the ability to re-create oneself to be perfect, which gives rise to the unrealistic expectation when entering into marriage. There do exist questions around this process of the 'recreation of the self in order to reach perfection'. Is it really within human abilities to create a perfect self? Differently put, is it within human abilities to create a false self?

Schweitzer (2004:61-62) states that 'human identity cannot adequately be interpreted as human achievement'. Identity should be understood as a gift one receives from God where he is constantly in the process of shaping it, and any person who tries to take over this role enters into a place of ideology (Schweitzer 2004:61-62). According to Louw (2012:62-66), a Christian spiritual approach to identity is determined by the 'understanding and experiencing of God'. It should not be the opinions on public platforms or the definition of a perfect 'selfie' that determines the identity of an individual. Instead, a healthy process of identity formation within a digital age should be accepted as a process that is founded on appropriate God-images (Van den Berg 2012:436) and specific values that flow out of these God-images as related to marriage. Pershey (2015) makes the following statement regarding identity formation in a digital age:

$[T]$ he avatar person constructed by the idol god is not, ultimately, our true self, the one knit together in a mother's womb by a 
Creator God. Perhaps it is an article of faith, in this strange new world, to confess that God knows us much more fully than any algorithm or digital trail ever could. (p. 13)

Accepting the above perspective brings the qualities uniquely associated with Christian marriage in reach of couples. Sacrificial love and unconditional acceptance serve as two examples within Christian marriage that only come to full fruition as spouses depend on God and, in faith, surrender to God's process of identity formation. This understanding of identity creates an awareness concerning the individualistic culture of identity formation in the digital age that does exist in a constant interplay with marriage relationships. Another important value in Christian marriage is that it represents a choice to accept responsibility for one another (Louw 2012:89). How one chooses to portray one's self online does affect one's offline marital relationship. Spouses can no longer think and act individualistically, but each decision and action will have an influence on one's spouse (Dreyer \& Van Aarde 2007:645).

This realisation, of the connection between mutual responsibility within marriage and self-presentation online, touches on the discussion around online infidelity. ${ }^{7}$ Numerous scholars have studied this recent phenomenon (Burton 2017; Carter 2015; Clayton et al. 2013; Gerson 2011; Hertlein \& Hawkins 2012; Isanejad \& Bagheri 2018; McDaniel, Drouin \& Cravens 2017; Pfeiffer 2011; Sahni \& Jain 2018; Whitty 2005). The present article focuses on studies that relate to the interplay between online identity formation and Christian marriages, as has been indicated.

There has been a global increase in divorce cases associated with online infidelity (Sahni \& Jain 2018:7). The fact that internet platforms provide a greater scope for secrecy and anonymity, the concealment of one's identity online, has been identified as a major contributing factor to the increase in divorce rates (Sahni \& Jain 2018:5). The number of online relationships that develop into offline relationships is not certain. Some research indicates that only a minority of online infidelity leads to offline relationships (Isanejad \& Bagheri 2018:543), whilst others indicate a majority (Whitty 2003:576, 2005:58). Regardless of these differences, researchers agree that the effect of online infidelity on the primary (offline) relationship is just as devastating as an affair in real life (Burton 2017:21; Carter 2015:3; Helsper \& Whitty 2010:923; Isanejad \& Bagheri 2018:543; Whitty 2005:65).

Whitty (2005) conducted a study amongst 234 participants to explore individual understandings of internet infidelity. The majority of participants did agree that internet infidelity is seen as real infidelity. Interestingly, there was a group of participants who indicated that online infidelity should not be

7.Internet infidelity is defined as a relationship that begins online "when a person despite having a committed relationship in reality, simultaneously engages in a romantic or sexual relationship with an internet partner secretly and without his/ her partner knowing'. These online sexual relationships include 'actions taken with the participation of others (such as cybersex)' as well as actions that exclude the participation of others (such as watching pornography) (Isanejad \& Bagher 2018:542). Furthermore, online infidelity is not only limited to a sexual element but also includes other components such as emotional infidelity and pornography (Whitty 2003:576). seen as real infidelity, because the 'relationship was with an object (computer) in virtual space, rather than with a real human being' (Whitty 2005:61). In a previous empirical study, Whitty (2003:576) found that actions in cyberspace carry the same weight as actions in the real world, even though there are no physical bodies present online. She explains this by referring to the 'reconstruction of the body online'. ${ }^{8}$ Her perception concerning this remains unchanged (Helsper \& Whitty 2010:923-924; Whitty 2005:58, 62), and other authors confirm that, regardless of the absence of one's physical body in a virtual world, online relationships are experienced to be on the same level of significance as offline relationships (Casey 2015:52-54; Joubert 2010:50-51). This understanding could be partly explained in a statement given by Joubert (2010:51) that people are involved in online interactions in their total existence, just like they would be present in offline relationships: all areas of that person's being, body, soul and spirit are involved in that online engagement.

Foundational to a pastoral anthropology is the concept of wholeness where the physical, bodily and non-physical, spiritual and soul-related qualities of a person's being exist interdependently (Dabrock 2010:143; McKeithen 2004:104). Consequently, it is accepted that online interaction involves the whole person in this sense, and online affairs cannot be justified because of the fact that no physical interaction exists in an online environment. It is indeed one's physical body that serves as the medium by which one can enter into virtual reality: therefore, separating body from online experiences does not seem logical. Regardless of whether online infidelity is explained as existing only within the person's mind, it does involve the entire being of that person.

This foundational principle of wholeness suggests that spouses intimately connect on all levels: body, soul and spirit bringing forth one-ness in marriage. What makes this unique within Christian marriage is the quality of togetherness that exists within this one-ness that involves three role players, that of the two spouses and Christ (Louw 2012:87-90, 2013:24). Dreyer and Van Aarde (2007:635-636) refer to Genesis 2:23-24 in explaining that the principle of becoming one flesh was God's initial plan for marriage, and it does not only refer to a unity in sexual relations but also includes one-ness on the level of spirit and soul. This resonates with an explanation by Louw (2012:90-92), mentioned above, of we-space as crucial for continual growth in marriage. According to Dreyer and Van Aarde, this concept of one-ness actually brings forth change in the spouse's identity, developing from being individualistic to relational focused (Dreyer \& Van Aarde 2007:636). A shared identity within marriage whereby the individual expands the self to include the other is, therefore, a crucial element of oneness within marriage. The destructive effect of infidelity on Christian marriages, whether online or offline, exists within the disruption of the oneness of the relationship by jeopardising values such as trust, authenticity, loyalty and transparency. Gerson (2011:149) makes use of a concept similar to one-ness when he states that every couple has a 'narrative, a shared story that provides an identity of bonding'. The following 8.See Van den Berg (2012) for a pastoral perspective on absent bodies in a virtual world. 
quote serves a well-articulated summary of what has been discovered in this article regarding online infidelity and identity formation in a digital age:

[T] he couple narrative invariably includes rules of fidelity, however elastic they may be, that is, what constitutes loyalty and security. Fidelity is a central narrative element in the storyline of mating. When there is a betrayal of fidelity, in whatever way it is defined, the narrative fractures. I think that all story making, and the security it provides, is jeopardised in cyberspace... What happens to the shared couple narrative, the narrative of fidelity and dependency, in a world in which self-states become independently engaged? Cyberspace offers intense activation of suppressed or inactive aspects of self...In the company of alternative selves, how do we design moral categories of intimate engagement? (Gerson 2011:149)

\section{Conclusion}

This article has attempted to provide a pastoral perspective on the interplay between online identity formation and Christian marriages. It has been demonstrated that identity formation in the digital age is accepted as a lifelong fluid process. The virtual world confronts individuals of different ages with the option to maintain multiple self-presentations on various digital platforms. Marriage serves as an environment where the continual development of the self takes on a relational element, which brings the vital concept of the 'we-space' into the discussion. We-space or one-ness takes on a unique quality within Christian marriage, which exists within a constant interplay amongst various elements of online identity formation. Important challenges arise because of the flexibility, quality and flourishing of the one-ness in Christian marriages amidst the interplay with online identities. A subsequent article will build on the discoveries made up to the present stage, elaborating on pastoral resources that can be offered to support the flourishing of Christian marriages in the digital age.

\section{Acknowledgements}

This article is derived from a PhD project, entitled Enhancing the resilience of Christian marriages in the digital age: A pastoral study. This study was conducted by the first author within the department of a practical theology of the Faculty of Theology's Research Unit for Reformational Theology and the Development of the South African Society, North-West University. The completed PhD study was submitted for examination in March 2021.

\section{Competing interests}

The authors declare that they have no financial or personal relationships that may have inappropriately influenced them in writing this article.

\section{Authors' contributions}

C.F. was responsible for conceptualising the article. H.Y. and A.B. were the promoters of this $\mathrm{PhD}$ research project and provided guidance throughout the process of writing, reviewing and editing the article.

\section{Ethical considerations}

This article followed all ethical standards for research without direct contact with human or animal subjects.

\section{Funding information}

This research received no specific grant from any funding agency in the public, commercial or not-for-profit sectors.

\section{Data availability}

Data sharing is not applicable to this article as no new data were created or analysed in this study.

\section{Disclaimer}

The views and opinions expressed in this article are those of the authors and do not necessarily reflect the official policy or position of any affiliated agency of the authors.

\section{References}

Abramians, I., 2016, 'Marriage in a digital age: Exploring the role of smart devices in marital relationships', PhD thesis, The Chicago School of Professional Psychology, Chicago, IL.

Aron, E.N. \& Aron, A., 1996, 'Love and expansion of the self: The state of the model', Personal Relationships 3(1), 45-58. https://doi.org/10.1111/j.1475-6811.1996. tb00103.x

Bailenson, J., 2013, 'Infinite reality: Avatars, eternal life, new worlds, and the dawn of the virtual revolution', IEEE Transactions on Visualization and Computer Graphics 19(4), xiv-xiv. https://doi.org/10.1109/TVCG.2013.50

Baltes, P.B., 1987, 'Theoretical propositions of life-span developmental psychology: On the dynamics between growth and decline', Developmental Psychology 23(5), 611-626. https://doi.org/10.1037/0012-1649.23.5.611

Baym, N.K., 2010, Personal connections in the digital age, Polity, Cambridge.

Baym, N.K., 2015, Personal connections in the digital age, 2nd edn., Polity, Cambridge.

Bengston, V., Putney, N. \& Johnson, M., 2005, 'Introduction and overview: The problem of theory in Gerontology today', in M.L. Johnson (ed.), The Cambridge handbook of age and ageing, pp. 3-21, Cambridge University Press, New York, NY.

Bingaman, K.A., 2006, 'The postmodern life cycle and pastoral care and counseling', Journal of Spirituality in Mental Health 9(1), 83-94. https://doi.org/10.1300/ J515v09n01_05

Boyd, D., 2014, It's complicated: The social lives of networked teens, Kindle edn., Yale University Press, London.

Burton, D.O., 2017, 'Do social networking sites influence Christian marriages?', PhD dissertation, The Chicago School of Professional Psychology, Chicago, IL.

Carpenter, C.J. \& Spottswood, E.L., 2013, 'Exploring romantic relationships on social networking sites using the self-expansion model', Computers in Human Behavior 29(4), 1531-1537. https://doi.org/10.1016/j.chb.2013.01.021

Carter, Z.A., 2015, 'Married and previously married men and women perceptions of communication on Facebook with the opposite sex: How communicating through Facebook can be damaging to marriages', PhD thesis, Regent University, Virginia Beach, VA.

Casey, S.B., 2015, 'The emergence of virtual identities, relations, and realities that arise from digital communications: Implications for therapy', PhD dissertation, University of Louisiana, Lafayette, LA.

Clayton, R.B., Nagurney, A. \& Smith, J.R., 2013, 'Cheating, breakup, and divorce: Is Facebook use to blame?', Cyberpsychology, Behavior \& Social Networking 16(10), 717-720. https://doi.org/10.1089/cyber.2012.0424

Cloete, A.L., 2015, 'Living in a digital culture: The need for theological reflection: Original research', HTS Teologiese Studies/Theological Studies 71(2), 1-7. https:// doi.org/10.4102/hts.v71i2.2073

Cloete, A.L., 2017, 'Technology and education: Challenges and opportunities', HTS Teologiese Studies/Theological Studies 73(3), a4589. https://doi.org/10.4102/hts. v73i3.4589

Cloete, A.L., 2019, 'Introduction', in A.L. Cloete (ed.), Interdisciplinary reflections on the interplay between religion, film and youth, pp. v-xii, SUN Press, Stellenbosch.

Cravens, J., Leckie, K. \& Whiting, J., 2013, 'Facebook infidelity: When poking becomes problematic', Contemporary Family Therapy: An International Journal 35(1), 74-90. https://doi.org/10.1007/s10591-012-9231-5

Dabrock, P., 2010, 'Drawing distinctions responsibly and concretely: A European protestant perspective on foundational theological bioethics', Christian Bioethics: Non-Ecumenical Studies in Medical Morality 16(2), 128-157. https://doi. org/10.1093/cb/cbq015 
Dereli, M.D., 2019, 'Fluidization of religious identities on cyberspace', The Journal of Humanity and Society 9(1), 85-115.

Dreyer, A.E. \& Van Aarde, A.G., 2007, 'Bybelse modelle van die huwelik: 'n Kritiese perspektief', HTS Teologiese Studies/Theological Studies 63(2), 625-651. https:// doi.org $/ 10.4102 /$ hts.v63i2.226

Erikson, M.J., 1998, 'Re-visioning the family life cycle theory and paradigm in marriage and family therapy', The American Journal of Family Therapy 26(4), 341-356. https://doi.org/10.1080/01926189808251112

Ferreira, C., 2016, 'Relationality in a digital age: A pastoral theological perspective on the counselling of couples', Unpublished MA thesis, North-West University.

Gerson, M., 2011, 'Cyberspace betrayal: Attachment in an era of virtual connection', Journal of Family Psychotherapy 22(2), 148-156. https://doi.org/10.1080/089753 53.2011.578039

Gratton, L. \& Scott, A., 2016, The 100 year life, Bloomsbury, London.

Halpern, D., Katz, J.E. \& Carril, C., 2016, 'The online ideal persona vs. the jealousy effect: Two explanations of why selfies are associated with lower-quality romantic relationships', Telematics and Informatics 34(1), 114-123. https://doi. relationships', Telematics and

Helsper, E.J. \& Whitty, M.T., 2010, 'Netiquette within married couples: Agreement about acceptable online behavior and surveillance between partners', Computers in Human Behavior 26(5), 916-926. https://doi.org/10.1016/j.chb.2010.02.006

Hertlein, K.M. \& Hawkins, B.P., 2012, 'Online gaming issues in offline couple relationships: A primer for marriage and family therapists (MFTs)', The Qualitative Report 17(15), 1-48.

Hertlein, K.M. \& Webster, M., 2008, 'Technology, relationships, and problems: A research synthesis', Journal of Marital \& Family Therapy 34(4), 445-460. https:// doi.org/10.1111/j.1752-0606.2008.00087.x

Isanejad, O. \& Bagheri, A., 2018, 'Marital quality, loneliness, and internet infidelity', Cyberpsychology, Behavior \& Social Networking 21(9), 542-554. https://doi. org/10.1089/cyber.2017.0602

Joubert, S.J., 2010, 'Annus Virtualis: Enkele uitdagings wat die virtuele era van Web 2.0 aan relevante kerklike bedieninge stel', Dutch Reformed Theological Journal: Nederduitse Gereformeerde Teologiese Tydskrif 51(3-4), 48-60. https://doi. org/10.5952/51-3-79

Larsen, J.L., Clauss-Ehlers, C.S. \& Cosden, M.A., 2015, 'An exploration of army wives' responses to spousal deployment: Stressors and protective factors', Couple and Family Psychology: Research and Practice 4(4), 212-228. https://doi.org/10.1037/ cfp0000049

Louw, D.J., 2012, Network of the human soul: On identity, dignity, maturity and life skills, African Sun Media, Stellenbosch.

Louw, D.J., 2013, Liefde is vir altyd, Lux Verbi, Kaapstad.

Louw, D.J., 2016, Wholeness in hope care: On nurturing the beauty of the human soul in spiritual healing, LIT, Berlin, Germany.

Marshall, T.C., 2012, 'Facebook surveillance of former romantic partners: Associations with postbreakup recovery and personal growth', Cyberpsychology, Behavior \& Social Networking 15(10), 521-526. https://doi.org/10.1089/ cyber.2012.0125

McDaniel, B.T., Drouin, M. \& Cravens, J.D., 2017, 'Do you have anything to hide? Infidelity-related behaviors on social media sites and marital satisfaction', Computers in Human Behavior 66, 88-95. https://doi.org/10.1016/j.chb. 2016.09.031
McInturff, K.O., 2018, 'Infidelity, marital satisfaction, and divorce intent among military married couples: Effects of social network sites activities', PhD thesis, Department of Philosophy, Northcentral University, San Diego, CA.

McKeithen, J.H.J., 2004, 'The nature of the human soul', in W.H. Lazareth (ed.), Persons in community, theological voices from the pastorate, pp. 98-105, Eerdmans, Grand Rapids, MI.

Meadows, M.S., 2008, I, avatar: The culture and consequences of having a second life, New Riders, Berkeley, CA.

Miller, V., 2011, Understanding digital culture, Sage, London.

Miller, V., 2020, Understanding digital culture 2, Sage, London.

Nielsen, A.C., 2019, 'Couples in the digital age: A systemic psychodynamic behavioral model of couple therapy', in P.J. Pitta \& C.C. Datchi (eds.), Integrative couple and family therapies: Treatment models for complex clinical issues, pp. 111-133, American Psychological Association, Worcester, MA.

O'Keefe, P.H., 2018, 'Using Facebook to communicate with husbands while deployed A qualitative study of army wives' experiences', Journal of Military and Government Counseling 6(2), 119-137.

Pershey, K.W., 2015, 'What Google doesn't know', Christian Century 132(20), 12-13.

Pfeiffer, K., 2011, 'Virtual adultery: No physical harm, no foul comment', University of Richmond Law Review 2, 667-690.

Sahni, S.P. \& Jain, G., 2018, Internet infidelity: An interdisciplinary insight in a global context, viewed 20 August 2020, from https://link-springer-com.nwulib.nwu. ac.za/book/10.1007\%2F978-981-10-5412-9.

Schweitzer, F.L., 2004, The postmodern life cycle, Chalice Press, St. Louis, MO.

Sugarman, L., 2001, Life-span development: Frameworks, accounts and strategies, Psychology Press, Hove.

Turkle, S., 2011, Alone together: Why we expect more from technology and less from each other, Basic Books, New York, NY.

Turkle, S., 2016, Reclaiming conversation: The power of talk in a digital age, Penguin Books, New York, NY.

Van den Berg, J.A., 2012, 'An anthropology of singularity? Pastoral perspectives for an embodied spirituality in the annus virtualis and beyond', in A. López-Varela (ed.), Social sciences and cultural studies, issues of language, public opinion, education and welfare, pp. 429-440, InTech Publishers, Rijeka.

Van den Berg, J.A., 2018, 'Tweeting God: A practical theological analysis of the communication of Christian motifs on Twitter', Unpublished PhD thesis, The University of Queensland.

Whitty, M.T., 2003, 'Pushing the wrong buttons: Men's and women's attitudes toward online and offline infidelity', Cyberpsychology \& Behavior 6(6), 569-579. https:// doi.org/10.1089/109493103322725342

Whitty, M.T., 2005, 'The realness of cybercheating: Men's and women's representations of unfaithful internet relationships', Social Science Computer Review 23(1), 57-67. https://doi.org/10.1177/0894439304271536

Wright, E., 2019, 'Fascilitating holistic identity formation of adolesents using digital media: A dialogue between media literacy and catholic religious education', in A. Cloete (ed.), Interdisciplinary reflections on the interplay between religion, film and youth, pp. 33-50, SUN Press, Stellenbosch.

Yee, N., Bailenson, J.N. \& Ducheneaut, N., 2009, 'The proteus effect: Implications of ransformed digital self-representation on online and offline behavior', Communication Research 36(2), 285-312. https://doi.org/101177/009365 0208330254 